\title{
STRATEGI PERPUSTAKAAN DAN PENINGKATAN KOMPETENSI PUSTAKAWAN DALAM MENDUKUNG TRI DHARMA PERGURUAN TINGGI
}

\author{
Agung Nugrohoadhi \\ Pustakawan Universitas Atma Jaya Yogyakarta \\ Email: agungnugrohoadhi@ymail.com
}

\begin{abstract}
In doing the service of the library can not be separated from the role of librarians as actors who must run the motion of the library so that all the efforts of librarians are deployed so that the library becomes one where the academic community to find the information it needs. Especially with the condition of this global world, the information is so easy to obtain and will have implications for librarians to continue to strive for the information presented always has a significant level of novelty so that with the development of information technology will help librarians in providing information services more quickly. The existence of an agreement between the library and faculty to digitize the collection of this thesis will facilitate the performance of librarians who served in digital services. The criteria for determining digital collections are very important to do so not all collections should be digitized. According to the author of digital collection collection is still required for the presented in the digital collection is the information that does have the added value to the reader or reader. Now with the dissemination of information that can be accessed anywhere will make it easier for the user to obtain information. In the civilization of the Indonesian people who have not had the awareness of reading in the sense of truly reading to get something needed becomes an easy gap to be entered by this hoax
\end{abstract}

Key word : Competency, Library, Librarian, Tri Dharma Perguruan Tinggi

\section{Latar Belakang Masalah}

Perpustakaan dalam layanannya tentu tidak jauh dari kegiatan proses belajar mengajar khususnya dikalangan perguruan tinggi. Masyarakat sering menyebut perpustakaan sebagai “jantungnya perguruan tinggi”. Pengibaratan ini menunjukkan bahwa perpustakan merupakan salah satu unit penyangga pilar pendidikan untuk memberikan kontribusinya dalam memberikan pengembangan wawasan keilmuwan bagi segenap sivitas akademika perguruan tinggi. Jantung merupakan organ dalam tubuh manusia yang bertugas untuk memompa darah manusia sehingga kehidupan manusia dapat berlangsung, apabila jantung berhenti bekerja, maka kehidupan manusiapun akan berhenti. Demikian pula perpustakaan apabila tidak ada dinamika dalam layanan perpustakaan, maka proses belajar mengajar sebuah perguraun tinggi dipastikan akan mengalami gangguan pula.

Dalam melakukan layanan tentu perpustakaan tidak lepas dari peran pustakawan sebagai personal yang harus menjalankan gerak perpustakaan sehingga segala daya upaya pustakawan dikerahkan agar perpustakaan menjadi salah satu tempat sivitas 
akademika mencari informasi yang diperlukannya. Apalagi dengan kondisi dunia global ini, informasi begitu mudah diperoleh dan akan mempunyai implikasi bagi pustakawan untuk terus mengupayakan agar informasi yang disajikan selalu mempunyai tingkat kebaruan yang signifikan sehingga dengan perkembangan teknologi informasi ini akan membantu pustakawan dalam memberikan layanan informasi secara lebih cepat dan akurat.

Mengingat pentingnya informasi yang dibutuhkan oleh pemustaka maka perpustakaan melakukan berbagai strategi agar segera informasi dapat dilayankan oleh pustakawan melalui cara-cara seperti pemencaran informasi sehingga layanan ini akan merupakan layanan unggulan dari perpustakaan agar setiap informasi yang ada dapat segera dapat diketahui oleh pemustaka. Maka salah satu strategi pustakawan agar dapat mengoptimalkan layanannya adalah bagaimana mengupayakan pemustaka memperoleh informasi secara cepat dan mudah dalam mengakses informasi-informasi yang diperlukan dengan dukungan teknologi informasi perpustakaan yang lebih maju sehingga pemustaka memperoleh kesan yang baik dengan institusi perpustakaan.

Saat ini begitu banyak layanan dalam menyelenggarakan aktivitas kepustakawananya sehingga profesi pustakawan akan semakin nampak aksi nyatanya dalam turut mengembangkan aktivitas intelektual bahkan dalam melakukan strategi strategi untuk mengembangkan peran sertanya di kalangan perguruan tinggi. Dunia intelektual yang penuh dinamika akan memacu perkembangan ilmu pengetahuan dan akan semakin berkembang sehingga mau tidak mau pustakawan harus mengambil peran dalam sistem kerja pustakawan yang akan semakin baik. Realitas ini menandakan bahwa kinerja pustakawan sangat dipengaruhi oleh perubahan kondisi di sekitarnya. Kalau saat ini perpustakaan digital telah menjadi dogma dalam perkembangan perpustakan yang modern, maka upaya-upaya perpustakaan menuju ke arah digitalisasi koleksi perpustakaan menjadi sistem layanan yang harus dilakukan oleh pustakawan. Dengan mengoptimalkan layanan yang berbasis digital maka diharapkan pemustaka akan memperoleh kepuasan ketika akan memperoleh jawaban informasi dari sejumlah pertanyaan-pertanyaan yang ingin memperoleh jawaban dari perpustakaan. Maka perpustakaan perguruan tinggi seharusnya menjadi roh bagi perguruan tinggi yang diwujudkan dalam layanan-layanan yang mempunyai wawasan keilmuan yang luas sehingga koleksi yang dimilikinya selalu mengikuti perkembangan ilmu pengetahuan dan teknologi. Bagi sivitas akademika 
perpustakaan berfungsi sebagai sumber informasi dan ini jelas akan menaikkan peran perpustakaan sehingga akan menggerakkan perpustakaan sebagai unit yang mempunyai posisi penting dalam dunia perguruan tinggi. Untuk itu diperlukan pustakawan-pustakawan yang dapat membantu memecahkan permasalahan yang dihadapi oleh sivitas akademika dalam mencari informasi yang dicarinya. Maka tidaklah salah apabila pustakawan menempatkan diri sebagai fasilitator yang siap membantu pemustaka dalam pencarian informasi yang diperlukan oleh pemustaka sehingga keberadaan perpustakaan dapat dirasakan manfaatnya. Hal ini didayagunakan jika keberadaannya memang mempunyai nilai tambah bagi pengembangan ilmu pengetahuan dengan menyediakan koleksi-koleksi yang relevan dengan kebutuhannya. Langkah awal agar keberadaannya dapat diakui adalah dengan memperkaya informasi yang berorientasi kepada kebutuhan pemustaka (customer oriented). Demikian halnya dengan perpustakaan khususnya perpustakaan perguruan tinggi sudah seharusnya dalam setiap kegiatan pengelolaan informasi diselaraskan dengan visi dan misi perguruan tinggi yang menaunginya (Tristiana Candra Dewi, 2006 : 1).

Dalam teknologi digital ini perpustakaan akan melayankan koleksi koleksi dalam format digital yang akan mempunyai beberapa keuntungan yaitu pemencaran informasi yang lebih meluas.Tak terbantahkan bahwa koleksi digital akan memperkaya pada publikasi ilmiah yang semakin bervariatif melalui penyedian publikasi online baik e-journal, e-book ataupun koleksi repository institusi yang akan bermanfaat bagi pengembangan koleksi digital perpustakaan. Maka tak pelak perubahan orientasi koleksi ini akan membawa implikasi bagi pengembangan kemampuan diri pustakawan mengikuti tren teknologi informasi yang semakin berkembang. Maka muncullah idiom pustakawan dengan peran baru yang tidak sekedar melayani pinjam dan kembalinya koleksi pustaka seperti pada masa masa lalu namun pustakawan lebih banyak berperan dalam pengolahan informasi untuk dapat didayagunakan bagi pengembangan ilmu pengetahuan.

Kedudukan perpustakaan dalam perguruan tinggi saat ini diharapkan mampu memberikan kontribusinya dalam membantu dalam penyediaan koleksi baik tercetak ataupun dalam bentuk online karena saat ini perpustakaan perguruan tinggi juga tidak hanya melayani dalam mendukung proses belajar mengajar sivitas akademika namun juga mendukung dalam kajian-kajian keilmuan melalui penelitian-penelitian yang dilakukan oleh sivitas akademika. Maka untuk mendukung agar mereka untuk lebih 
produktif, perpustakaan dapat memberikan publikasi ilmiah yang mencukupi sehingga pengembangan penelitian dikalangan perguruan tinggi mempunyai bobot yang lebih baik. Pustakawan untuk dapat melakukan fungsinya sebagai seorang yang berkecimpung dalam informasi dengan memberikan saran bagi para peneliti tentang sumber-sumber publikasi ilmiah yang dapat dipergunakan sebagai literatur untuk mengembangkan penelitian-penelitian yang sudah ada. Saat ini daya saing sumber daya menusia (SDM) dan penguasaan ilmu pengetahuan serta teknologi di Indonesia belum begitu menggembirakan. Maka kehadiran perpustakaan yang mempunyai kualitas baik tentu tidak segan-segan untuk dapat mencari terobosan dalam melakukan jaringan-jaringan terhadap penyediaan publikasi ilmiah bagi pengembangan riset.

Strategi menghadapi era kompetitif dikalangan perguruan tinggi juga mempunyai implikasi terhadap peningkatan kompetensi pustakawannya sendiri. Saat ini dengan perkembangan dunia informasi yang melesat seiring dengan tren masyarakat dan teknologi yang terus bergulir dan perkembangan pemikiran masyarakat yang selalu berkembang, menuntut pelayanan yang semakin baik bagi para pemustaka. Esensi perpustakaan sebagai salah satu sarana penyedia informasi memegang peranan penting dalam pembentukan masyarakat kompetitif. Hal ini karena untuk membentuk masyarakat kompetitif dan berdaya saing tentu harus diawali dengan pemberian informasi yang memadai. Perpustakaan harus meningkatkan diri tidak saja menjadi tempat mencari dan mengembangkan ilmu pengetahuan, namun juga bisa menjadi representasi dari jantung dari semua program pendidikan, pusat alat peraga pendidikan, pusat sumber daya dan pusat kegiatan social (Jazimatul Husna, 2016 : 61). Maka pustakawan dalam era kompetitif ini adalah meningkatkan kompetensinya dalam melayani .

Pustakawan merupakan suatu profesi, oleh karena itu seorang pustakawan seharusnya profesional dalam bidangnya. Untuk mendapatkan predikat profesional tersebut seharusnya seorang pustakawan harus memiliki sertifikat keahlian. Dan untuk mendapatkan sertifikat keahlian tersebut ia harus lulus dalam ujian sertifikasi. Jadi profesional tersebut tidak cukup hanya dengan memiliki ijazah akademik (kompetensi akademik) saja. Untuk menyusun standar kompetensi ini organisasi profesi dapat bekerjasama dengan Perpustakaan Nasional RI sebagai regulator dan perguruan tinggi sebagai pakar kepustakawanan. Pada saat yang sama, beberapa lembaga yang mampu dapat ditunjuk untuk menerbitkan sertifikasi. Untuk setiap 
jabatan/pekerjaan/job tersebut, perlu didefinisikan kompetensi ataupun kemampuannya (knowledge, skill, attitude). Dari kerjasama antara organisasi profesi dalam hal ini Ikatan Pustakawan Indonesia, Perpustakaan Nasional RI dan perguruan tinggi dapat dibuat standar kompetensi pustakawan di Indonesia. Kompetensi didefinisikan berdasarkan kebutuhan menjalankan suatu pekerjaan (job). Sebagaimana pada pekerjaan terdapat penjenjangan, demikian juga kompetensi memiliki penjenjangan menurut tingkat kesukaran. Sebagai contoh, pekerjaan otomasi perpustakaan membutuhkan kompetensi menggunakan perangkat lunak perpustakaan. Dari kompetensi ini dapat diturunkan pelatihan apa yang diharapkan membekali pustakawan tersebut untuk memiliki kompetensi ini. Kompetensi ini juga dipakai untuk menguji (mengassess) keberhasilan dari pelaksanaan pelatihan ini. Kemudian pelatihan ini dipaketkan dalam program studi yang diselenggarakan bagi pustakawan (Abdul Rahman Saleh,2004).

\section{Rumusan Masalah}

Dalam tulisan ini penulis ingin menjawab pertanyaan-pertanyaan yang akan dijawab dalam analisis atau isi dalam penjabaran dibawah ini.

1. Kompetensi apa saja yang harus dimiliki oleh seorang pustakawan dalam mendukung kegiatan tri dharma perguruan tinggi ?

2. Strategi-strategi apa saja yang harus dilakukan agar kompetensi yang harus dimiliki oleh pustakawan?

\section{Teori}

Untuk memberikan pemahaman kepada pembaca dengan judul Strategi Perpustakaan dan Peningkatan Kompetensi Pustakawan dalam Mendukung Tri Dharma Perguruan Tinggi maka, penulis sampaikan beberapa pengertian yang penulis pakai sebagai judul tulisan yaitu :

\section{Pengertian Perpustakaan}

Pengertian perpustakaan menurut Undang-undang No 43 tahun 2007 tentang perpustakaan pada Bab I pasal I menyatakan perpustakaan adalah institusi yang mengumpulkan pengetahuan tercetak dan terekam, mengelolanya dengan cara khusus guna memenuhi kebutuhan intelektualitas para penggunanya melalui beragam cara interaksi pengetahuan. Sulistyo Basuki mengatakan bahwa batasan perpustakaan 
adalah sebuah ruangan, bagian sebuah gedung itu sendiri yang digunakan untuk menyimpan buku dan terbitan lainnya yang biasanya disimpan menurut tata susunan tertentu untuk digunakan pembaca, bukan untuk dijual. Dalam pengertian buku dan terbitan lainnya termasuk didalamnya semua bahan cetak (buku, majalah, laporan. Pemflet, prosiding, manuskrip (naskah), lembaran musik, berbagai karya media audio visual seperti film, slaid (slide), kaset, piringan hitam bentuk mikro seperti microfilm, mikrofis dan mikroburam (Sulistyo Basuki, 3). Secara umum dapat disimpulkan bahwa pengertian perpustakaan adalah suatu institusi unit kerja yang menyimpan koleksi bahan pustaka secara sistematis dan mengelolanya dengan cara khusus sebagai sumber informasi dan dapat digunakan oleh pemakainya atau pemustaka. Namun saat ini pengertian tersebut diatas mulai mengalami pergeseran seiring dengan perubahan kondisi disekitarnya. Banyak kalangan terfokus untuk memandang perpustakaan sebagai sistem. Tidak lagi menggunakan pendekatan fisik. Sebagai sebuah sistem perpustakaan terdiri dari beberapa unit kerja atau bagian yang terintegrasikan melalui sistem yang dipakai untuk pengolahan, penyusunan dan pelayanan koleksi yang mendukung berjalannya fungsi-fungsi perpustakaan. Dalam perkembangan selanjutnya menempatkan perpustakaan menjadi sumber informasi ilmu pengetahuan, teknologi dan budaya . Dari istilah pustaka berkembang istilah pustakawan, kepustakaan, ilmu perpustakaan dan kepustakawanan (Ibid, 52) .

\section{Fungsi Perpustakaan}

Sulistyo Basuki seperti yang dikutip oleh Wji Suwarno memberikan gambaran fungsi perpustakaan dalam kehidupan masyarakat adalah sebagai berikut :

a. Fungsi simpan karya, yaitu fungsi perpustakaan untuk menyimpan buah karya masyarakat. Bentuk karya yang disimpan adalah yang berkaitan dengan buku, majalah, surat kabar atau informasi terekam lainnya. Perpustakaan berfungsi sebagai 'arsip umum" bagi produk masyarakat berupa buku dalam arti luas

b. Fungsi informasi, yaitu fungsi perpustakaan yang memberikan informasi sejelas-jelasnya kepada pemustaka tentang sesuatu hal yang diperlukan. Pada fungsi ini, anggota masyarakat yang memerlukan informasi dapat meminta atau menanyakan ke perpustakaan terutama mengenai substansi informasi yang dikelolanya. Informasi yang dikelola berupa informasi ilmiah atau 
informasi lainnya yang dianggap wajar untuk dikonsumsi masyarakat. Karena perkembangan pemikiran dan kebutuhan, fungsi informasi ini lebih ditekankan kepada pemberdayaannya. Dengan demikian diharapkan pemustaka ini mampu mengoptimalkan informasi yang didapat dari perpustakaan menjadi informasi baru yang dapat diakses oleh pemustaka lainnya

c. Fungsi pendidikan, yaitu fungsi perpustakaan yang menunjang sistem pembelajaran yang dicanangkan oleh pemerintah. Sejalan dengan perkembangan ilmu pengetahuan, perpustakaan sudah saatnya menjadi pusat sumber belajar dan penelitian masyarakat. Artinya, fungsi perpustakaan bukan semata sebagai pendukung kurikulum pendidikan, melainkan lebih dari itu menjadi tempat belajar dan penelitian bagi masyarakat. Pasal 2 UU No 43 tahun 2007 menyebutkan bahwa perpustakaan bertujuan memberikan layanan kepada pemustaka serta memperluas wawasan dan pengetahuan untuk mencerdaskan kehidupan bangsa.

d. Fungsi rekreasi, yaitu fungsi perpustakaan sebagai tempat yang menjadi rekreasi bagi pemustakanya dengan memberikan fasilitas yang baik dan bacaan yang sifatnya menghibur. Akan tetapi sekarang penekanannya bukan hanya rekreasinya, melainkan rekreasi dan re-kreasi, yaitu fungsi perpustakaan sebagai tempat yang nyaman dan menyajikan informasiinformasi yang sifatnya menyenangkan serta sebagai tempat yang menghasilkan kreasi (karya) baru yang berpijak dari karya-karya orang lain yang telah dipublikasikan.

e. Fungsi kultural, yaitu perpustakaan sebagai media dalam rangka melestarikan kebudayan bangsa. Pola pikir ini kemudian berkembang ke arah mengembangkan kebudayaan, yaitu fungsi perpustakaan sebagai tempat mengembangkan kebudayaan melalui penanaman nilai-nilai kepada masyarakat melalui berbagai kegiatan-kegiatan seperti pemutaran film dokumemter, belajar menari, les bahasa, story telling dan lain-lain (Wiji Suwarno, 30)

\section{Tri Dharma Perguruan Tinggi}

Secara etimologi bahasa, kata "Tri” sendiri berasal dari bahasa Sansekerta. "Tri” artinya tiga, sedangkan "Dharma” bermakna kewajiban. Tri Dharma Perguruan 
Tinggi merupakan jargon di setiap perguruan tinggi di Indonesia dengan berbagai macam disiplin ilmunya namun tetap mengedepankan tri dharma perguruan tinggi Dasar dan tanggung jawab tersebut dilakukan secara terus-menerus dan dikembangkan secara beriringan. Adanya Tri Dharma Perguruan Tinggi merupakan wujud dari keseriusan perguruan tinggi untuk menyajikan pendidikan yang berkualitas. Oleh karena itu, Tri Dharma Perguruan Tinggi sepatutnya telah menjadi budaya dan kesadaran.Tanggung jawab Tri Dharma Perguruan tinggi itu sendiri sebenarnya diberikan kepada seluruh sivitas akademik terutama dosen dan mahasiswa. Dosen sebagai pengajar, pembimbing sekaligus pendamping, sedangkan mahasiswa sebagai anak didik yang menuntut ilmu. Dua elemen ini akan terus berkaitan mengingat tak bisa disebut dosen tanpa adanya mahasiswa, begitu sebaliknya. Pertanyaannya, mengapa mahasiswa dan dosen? Di masa sebelum kemerdekaan bangsa Indonesia, dua elemen ini sangat berpengaruh dalam merumuskan cita-cita masa depan bangsa. Mahasiswa yang menjadi siswa kala itu telah terbukti turut berkontribusi dengan ide, gagasan, pikiran serta perjuangan fisik demi kemerdekaan melalui pekikan-pekikan perjuangan Sedangkan dosen (guru) telah terbukti melahirkan generasi-generasi emas pejuang kemerdekaan. Mereka menebarkan ilmu-ilmu baik secara tersembunyi maupun terang-terangan. Mereka itulah pejuang tanpa tanda jasa, bahkan tanpa tanda nama Pemaparan di atas, kiranya sudah memberikan gambaran mengenai pengertian Tri Dharma Perguruan Tinggi. Namun untuk mengerti maksud dari Tri Dharma Perguruan Tinggi kiranya masih memerlukan penjabaran yang luas dan mendalam.

\section{Pendidikan dan Pengajaran Sesuai Tri Dharma Perguruan Tinggi}

Melalui pendidikan di perguruan tinggi, mahasiswa akan berproses menjadi bibit-bibit unggul. Dalam hal ini, perguruan tinggilah yang berkewajiban melahirkan generasi-generasi emas. Adanya mahasiswa yang unggul dalam bidang ilmu pengetahuan tidak bisa terlepas dari peran perguruan tinggi itu sendiri. Perguruan tinggi baik swasta maupun negeri diberikan kebebasan tersendiri untuk menyusun konsep dari pendidikan. Adanya konsep yang jelas di atas diharapkan mampu membawa negara ke arah kemajuan. Kemajuan tersebut meliputi kemajuan budaya, mindset dan Iptek. Demi mencapai tujuan dari Tri Dharma Perguruan tinggi tersebut, mahasiswa dituntut aktif untuk mengeksplor, mencari dan menggali sendiri terkait keilmuan yang digeluti. Dengan demikian, mahasiswa sadar betul apa yang 
dilakukannya dan dalam rangka meraih keilmuan apa. Semakin spesifik keilmuan seseorang, maka semakin matang dan sempurna.

Saat berlangsungnya pendidikan dan pengajaran, pengajaran tidak hanya bertumpu pada diri dosen atau yang biasa disebut pendidikan komunikasi satu arah. Pendidikan yang berlangsung seharusnya meliputi komunikasi dua arah yang melibatkan keaktifan antara dosen dan mahasiswa. Konkritnya, dosen bukan hanya sebatas mentransfer ilmu dari gelas kosong menjadi berisi. Lebih dari itu, dosen pendidikan dituntut untuk merangsang daya pikir mahasiswa sehingga ilmu akan berkembang, bukan stagnan berjalan di tempat.

\section{Penelitian dan Pengembangan Sesuai Tri Dharma Perguruan Tinggi}

Dari tindak lanjut point pertama Tri Dharma Perguruan Tinggi di atas, pendidikan dan pengajaran selanjutnya diarahkan pada penelitian dan pengembangan. Tujuan dari point kedua ini mahasiswa dalam menuntut ilmu diharapkan tidak hanya sebatas tahu, namun mengerti dan mampu menjadi konseptor perkembangan zaman di masa depan. Begitu pentingnya penelitian dan pengembangan yang tertera di Tri Dharma Perguruan Tinggi. Maka penelitian dan pengembangan merupakan aktivitas jantungnya civitas akademik. Perguruan tinggi tanpa adanya penelitian akan dianggap sebagai perguruan tinggi yang tidak produktif. Selain itu, perguruan tinggi tanpa adanya penelitian akan dianggap sebagai perguruan tinggi yang tertinggal.Pentingnya sebuah penelitan dan pengembangan juga terletak pada updatenya keilmuan. Kampus dituntut menjadi problem solving sehingga mau tidak mau harus lebih cepat merespon isu-isu global, memberikan pencerahan, penjelasan dan sikap yang tepat untuk masyarakat mengenai apa yang sedang terjadi.

Mengingat derasnya arus perkembangan zaman yang sering berubah, sebuah penelitian biasanya belum tentu dapat dipraktikkan. Oleh sebab itu, adanya penelitian dan pengembangan diikhtiarkan dapat menjadi penelitian yang bisa secara riil menyelesaikan masalah. Konkritnya, ilmu tak akan menjadi ilmu bila kebermanfaatanya dipertanyakan.

\section{Pengabdian Masyarakat}

Baik dosen maupun mahasiswa, diharapkan untuk untuk memberikan pengabdian kepada masyarakat. Pengabdian tersebut dapat berupa penyebaran ilmu 
ke tempat peribadatan, acara warga maupun bentuk-bentuk tulisan di media massa. Demikian juga mahasiswa.Pengabdian inilah yang menuntut para akademisi untuk mempraktikkan ilmu-ilmu yang telah dipelajari di kampus. Sebab, ilmu tanpa dipraktikkan seperti tong konsong berbunyi nyaring.Oleh sebab itu, seorang akademisi benar-benar harus menjadi teladan bagi para akademisi lainnya terkhusus kepada masyarakat yang notabene adalah warga yang bias hidup bersama seharihari.Di zaman sekarang para akademisi sangat leluasa untuk melakukan dan melaksanakan dengan sepenuh hati segala bentuk pengabdian sesuai Tri Dharma Perguruan Tingi. Maka apabila seorang sivitas akademik di bidang media, kita dapat turut menjadi rantai kebaikan dengan menyebarkan konten-konten yang berkualitas.

Hal tersebut hanyalah contoh kecilnya saja. Jadi, mengabdi jangan hanya diartikan sempit turut kerja bakti di kampung halaman. Kita dapat mengeksplore keilmuan yang kita miliki dengan aksi-aksi yang banyak bermanfaat bagi orang banyak. Dalam hal pembelajaran, mahasiswa yang merantau perlu memperteguh diri bahwa menutut ilmu di perguruan tinggi harus dilakukan secara maksimal. Bila sudah tiba waktunya kembali ke kampung halaman, mahasiswa mampu mengabdikan dirinya terjun ke masyarakat membangun desa.(http://www.academicindonesia.com/tri-dharma-perguruan-tinggi/ dikutip 2 Juni 2017, pukul 19.13)

\section{Kompetensi}

Dalam Undang undang Nomor 43 tahun 2007 banyak termuat istilah mengenai profesionalisme pustakawan atau unsur-unsur terkait, misalnya profesi, kompetensi, standarisasi, tenaga perpustakaan, pendidikan dan pengembangan , organisasi profesi, pembinaan karier dan kode etik. Profesionalisme pada hakekatnya merupakan pengakuan pihak luar terhadap kompetensi kinerja, sikap dan layanan yang diberikan seorang professional apapun profesinya. Dalam UU perpustakaan, secara tegas, eksplisit dinyatakan bahwa perpustakaan harus mampu mengelola perpustakaan agar tujuan perpustakaan sebagai wahana pendidikan, penelitian, pelestarian, informasi dan rekreasi dapat diperoleh pemustaka. Sedangkan tuntutan dalam kelembagaan atau institusi, perpustakaan diselenggarakan berdasarkan ass pembelajaran sepanjang hayat, demokrasi, keadilan, keprofesionalisan, keterbukaan, keterukuran dan kemitraan (pasal 2). Untuk mengemban amanah dan tugas UU tersebut kompetensi pustakawan merupakan 
tuntutan dan keharusan yang mutlak dimiliki oleh seorang pustakawan. Sedangkan kompetensi berupa pendidikan formal maupun nonformal dapat dilakukan pola kemitraan atau kerjasama antar institusi, baik oleh perpustakaan nasional, perpustakaan di tingkat propinsi, kabupaten/kota dengan lembaga pendidikan atau organisasi profesi (pasal 33 ayat 3) (Sungkowo Raharjo, 2010 : 13).

Saat ini pustakawan diharapkan untuk dapat mengikuti sertifikasi pustakawan sehingga profesi pustakawan dapat dinyatakan sebagai seorang professional setelah melalui ujian kompetensi pustakawan yang diselenggarakan oleh perpustakaan nasional. Standar kompetensi dapat disusun oleh organisasi profesi bekerjasama dengan perpustakaan nasional dengan melibatkan berbagai jenis perpustakaan. Kompetensi memang menjadi suatu hal yang sangat penting . Karena selama ini citra pustakawan belum mendapatkan tempat yang membanggakan karena salah satu aspek yang belum dimiliki adalah kompetensi. Aspey dalam Sungkowo menekankan bahwa kompetensi tidak hanya meliputi penguasaan keterampilan dan pengetahuan saja, tetapi juga termasuk penguasaan terhadap tugas dan motivasi dalam menjalankan tugas tersebut. Aspey juga mendefinisikan "orang yang berkompeten" sebagai seorang yang menguasai pekerjaan dan memiliki motivasi, keterampilan serta pengetahuan dan secara konsisten menjalankan tanggungjawab tersebut dengan memenuhi standar yang ditetapkan. Dengan kata lain, kompetensi seseorang diukur dengan membandingkan kinerja yang bersangkutan dengan tingkat pstandar tertentu yang ditetapkan. (Sungkowo, 2010,17).

Sebagai acuan berikut adaptasi standar kompetensi yang diberlakukan untuk perpustakaan sekolah /madrasah yang dituangkan dalam keputusan Mendiknas nomor 25 tahun 2008 yang dapat juga dimaknai sebagai standar kompetensi pustakawan pada secara umum yaitu :

1. Kompetensi manajerial

- Melaksanakan kebijakan organisasi

- Membantu merencanakan program perpustakaan

- Melaksanakan program

- Memantau pelaksanaan program

- Menevaluasi program

2. Kompetensi pengelolaan informasi

- Membantu mengembangkan koleksi

- Mengorganisasi informasi (pekerjaan teknis perpustakaan) 
- Memberikan jasa dan sumber informasi

- Menerapkan teknologi informasi dan komunikasi

- Kemampuan berbahasa Inggris

- Penguasaan komputer

- Mengembagkan keterampilan memanfaatkan informasi

- Memberikan bimbingan literasi informasi

3. Kompetensi kelembagaan

- Memahami tupoksi organisasi secara menyeluruh dan mendalam

- Memahami bidang ilmu sesuai tujuan lembaga induknya

- Memahami program dan kegiatan

4. Kompetensi kepribadian

- memiliki integritas yang tinggi

- memiliki etos kerja yang tinggi

5. kompetensi social

- membangun hubungan social

- membangun komunikasi

- memelihara kerjasama tim

- mempromosikan perpustakaan

6. kompetensi penegmbangan profesi

- mengembangkan ilmu

- menghayati etika profesi

- menunjukkan kebiasaan membaca (Aan Permana, 2010: :8-9)

Berdasarkan kondisi diatas, setidaknya terdapat dua kategori kompetensi yag harus dimiliki pustakawan yaitu :

1. kompetensi professional, yaitu kemahiran merancang, melaksanakan dan menilai tugas sebagai pustakawan yang meliputi penguasaan ilmu pengetahuan dan teknologi informasi dan komunikasi

2. kompetensi personal, yang meliputi etika, moral, pengabdian, kemampuan soail dan spiritual.

\section{Pustakawan}

Menurut Undang-undang perpustakaan No 43 tahun 2007, disebutkan bahwa pustakawan adalah seorang yang memiliki kompetensi yang diperoleh melalui pendidikan dan/atau pelatihan kepustakawanan serta mempunyai tugas dan 
tanggungjawab untuk melaksanakan pengelolaan dan pelayanan perpustakaan (RI, 2007: 4). Dalam International Encyclopedia of Information and Library Science Second edition, pustakawan dijelaskan sebagi berikut :

"Traditionally, and still in popular consciousness, the curator of collections of book and other information materials, administering conditional user access to information for user groups of various descriptions, still initially through collections of information materials under their immediate administration, but also through the global range of available sources " (International Encyclopedia 2003:370).

Definisi di atas menjelaskan bahwa pustakawan secara tradisional masih dipahami secara umum merupakan kurator buku dan bahan-bahan informasi lainnya yang akan memberikan layanan kepada pemustaka dalam mengakses informasi. Pengertian lain pustakawan menurut ODLIS (Online Dictionary of Library and Information Science) :

"A professionally trained person responsible for the care of a library and its contens, including the selection, processing and organization of materials and the delivery of information, instruction and loan service to meet the needs of its users. In an online environment the role of the librarian is to manage and mediate access to information which may exist only in electronic form(Joan, 2002: 2).

Pengertian ODLIS nampaknya menggabungkan antara pengertian pustakawan yang dikemukakan sebelumnya, yaitu mensyaratkan pendidikan khusus dalam menjalankan tugas-tugas kepustakawanannya. Hanya saja ada tambahan bahwa pustakawan harus mampu menjadi pengelola dan perantara akses terhadap informasi yang sebagian sudah berbentuk media elektronik (Ibid).

Menurut Keputusan Menpan No 132/KEP/M. PAN/12/2002 dalam pasal 3 menyatakan bahwa "pustakawan adalah pejabat fungsional yang berkedudukan sebagai pelaksana penyelenggara tugas utama kepustakawanan pada unit-unit perpustakaan, dokumentasi dan informasi pada instansi pemerintah dan atau unit tertentu lainnya. Pustakawan dalam pengertian ini terdiri dari pustakawan tingkat terampil dan pustakawan tingkat ahli. Pustakawan tingkat terampil adalah pustakawan yang memiliki dasar pendidikan untuk pengangkatan pertama serendahrendahnya Diploma II Perpustakaan Dokumentasi dan Informasi atau Diploma bidang lain yang disetarakan. Pustakawan tingkat ahli adalah Pustakawan yang memiliki dasar pendidikan untuk pengangkatan pertamakali serendah-rendahnya 
Sarjana Perpustakaan, Dokumentasi dan Informasi atau sarjana bidang lain yang disetarakan.Sedangkan menurut peraturan Jabatan Fungsional Pustakawan pada Universitas Atma Jaya Yogyakarta nomor 01/perat/YSRY/2009 pustakawan adalah pegawai tetap YSRY yang dipekerjakan di UAJY yang diberi tugas, wewenang dan hak secara penuh oleh YSRY untuk melakukan kegiatan kepustakawanan.

\section{Metode}

Penulisan ini menggunakan metode dengan pendekatan studi literatur dengan pendekatan kualitatif. Menurut Putu Laxman Pendit pendekatan kuantitatif dengan salah satu cirri utamanya, yitu pengukuran (measurement) atau pengujian berdasarkan ukuran tertentu walaupun tidak selalu menggunakan metode statistik. Sedangkan penelitian kualitatif atau penelitian dengan menggunakan kualitatif lebih cocok untk situasi yang sedang dan masih berkembang sehingga lebih memerlukan penjelajahan atau eksplorasi dan bukan pengukuran. Penelitian kualitatif juga dianggap lebih tepat atau untuk penelitian yang bertujuan mendalami, memaknai atau memahami fenomena sosial tertentu (Putu Laxman Pendit, 18-19). Metode ini selaras dengan tema penulisan ini yang berkaitan dengan kompetensi pustakawan yang terus berubah sesuai dengan fenomena yang terjadi dalam dunia teknologi informasi karena pustakawan saat ini harus mau berubah mengikuti tren pemustaka yang selalu mengininkan informasi yang selalu update

\section{Strategi Dalam Peningkatan Pendidikan}

Dalam menggalakkan fungsi perpustakaan sebagai bagian dari entitas perguruan tinggi, perpustakaan terutama dalam bidang pendidikan dapat bekerjasama dengan kepala-kepala program studi untuk dapat mengadakan pertemuan secara rutin misalnya pada awal semester tahun akademik untuk membahas tentang koleksikoleksi yang harus dilakukan pembelian oleh perpustakaan sehingga setiap pembelian-pembelian koleksi adalah selaras dengan silabus masing-masing program studi. Pertemuan-pertemuan ini sangat penting khususnya dalam pengadaan bukubuku wajib sesuai yang tertera dalam silabus, demikian juga salah satu koleksi yang penting saaat ini adalah koleksi jurnal baik cetak ataupun online. Maka pengadaan koleksi ini tetap harus dibicarakan dengan ketua program studi mengingat jurnaljurnal terutama yang terakreditasi menjadi salah satu komponen yang ikut mempengaruhi dalam akreditasi program studi . 
Saat ini merupakan tantangan sendiri bagi pustakawan bahwa yang dilayani oleh pustakawan adalah pemustaka-pemustaka yang sudah begitu paham tentang teknologi informasi sehingga hal ini menjadi tantanagan bagi pustakawan untuk meningkatkan kompetensi pustakawan dalam bidang teknologi informasi. Maka inovasi-inovasi dari perpustakaan tetap harus dilakukan oleh pustakawannya. Prof. Dwikorita mengatakan bahwa salah satu upaya yang bisa dilakukan perguruan tinggi untuk meningkatkan daya saing adalah melakukan perubahan paradigma lembaga perguruan tinggi dalam upaya melakukan reorientasi akademik. Penguatan riset perlu dilakukan agar bisa menghasilkan produk penelitian yang semakin inovatif ( Dwikorita, 2016). Dari sinilah peran pustakawan untuk melakukan inovasi terutama dalam mengusahakan perpustakaan yang dapat menyediakan layanan berjejaring atau sumber-sumber publikasi yang diperoleh melalui kerjasama antar perguruan tinggi yang nantinya juga akan membawa implikasi bagi kerjasama antar perpustakaan perguruan tinggi.

Maka inovasi dalam pengadaan koleksi yang harus disediakan misalnya dalam buku-buku elektronik merupakan salah satu strategi pihak perpustakaan agar koleksi tercetak yang kadang-kadang terbatas dapat dilayankan secara elektronik sehingga dapat dinikmati oleh pemustaka secara bersama-sama bahkan seperti dikatakan oleh Eko Yulianto Napitupulu seorang manajer Prasetya Mulya Publishing, perguruan tinggi yang memiliki bidang keilmuan yang sama bisa bersinergi untuk mengelola jurnal. Tujuannya agar frekuensi penerbitan bisa ditingkatkan. Dengan demikian semakin banyak artikel ilmiah yang dapat dimuat dari kalangan perguruan tinggi. Dengan berjejaring, jurnal ilmiah bisa ditingkatkan hingga mencapai jurnal ilmiah bereputasi, misalnya terindeks Scopus yag saat ini di Indonesia baru ada 28 Jurnal ilmiah (Eko Yulianto, 2017) Pustakawan dengan penguasaan teknologi informasinya dapat melakukan peningkatan publikasi ilmiah melalui peningkatan repository institusi dengan media online yang dimiliki perpustakaan dapat mempublikasikan karya-karya penelitian staf sivitas akademika. Bahkan dengan menggalakkan publikasi melalui online atau daring ini terbuka kesempatan untuk membangun jejaring dan sinergi dengan masyarakat industri dalam rangka hilirisasi riset yang sangat ini konektivitas perguruanntinggi dan industri belum terhubung dengan baik. Berbagai produk riset belum banyak dimanfaatkan oleh masyarakat . Maka disinilah peran perpustakaan dalam pemencaran riset atau diseminasi riset unggulan sangat 
diperlukan terutama dapat ditangani oleh pustakawan-pustakawan yang mempunyai kompetensi dalam pemanfaatan teknologi informasi yang semakin meluas ini.

Sesuai dengan pengalaman penulis, dalam perpustakaan dapat dibentuk Tim Pengembangan Koleksi yang bertugas secara ad hoc. Tim ini merupakan bagian yang lepas dari struktur dalam perpustakaan sehingga anggota tim yang ada dalam tim itu adalah pustakawan-pustakawan yang biasa menangani bidang pengadaan buku cetak, surat kabar harian, pengadaan jurnal maupun pengadan jurnal-jurnal online sehingga tim ini dapat melakukan komunikasi secara intensif dengan para kepala program studi bahkan tidak saja dalam pertemuan-pertemuan formal namun juga dapat melalui komunikasi melalui telpon ataupun email dapat melakukan komunikasi-komunikasi yang membangun untuk mencapai kebutuhan buku yang diselaraskan dengan silabus ataupun pengadaan jurnal-jurnal terakreditasi untuk mendukung akreditasi program studi .

\section{Strategi Dalam Peningkatan Kompetensi Penelitian}

Dunia perguruan tinggi tidak lepas dari penelitian yang dilakukan oleh staf pengajar ataupun para mahasiswa dalam menyelesaikan tugas akhirnya. Staf pengajar atau dosen merupakan kewajiban untuk terus melakukan penelitian sebagai syarat untuk kenaikan pangkatnya bahkan melakukan penelitian bagi dosen merupakan pengungkapan atas dirinya sebagai seorang intelektual yang dituangkan dalam gagasan-gagasan ataupun temuan-temuan ilmiah yang dapat diuji dengan teori-teori yang menjadi dasar untuk menunjukkan kesahihan atas penelitiannya. Bagi mahasiswa Strata S1, S2 ataupun S3, melakukan penelitian adalah sebagai syarat utama untuk kelulusannya sehingga perguruan tinggi memang identik dengan penelitian penelitian akademik atau ilmiah yang dilakukan oleh sivitas akademika.

Adanya kesepakatan antara perpustakaan dan fakultas untuk mendigitalkan koleksi skripsi ini akan mempermudah kinerja pustakawan yang bertugas di layanan digital. Kriteria dalam menentukan koleksi digital amat penting untuk dilakukan sehingga tidak semua koleksi harus didigitalkan. Menurut penulis seleksi koleksi digital tetaplah diperlukan agar yang tersaji dalam koleksi digital adalah informasiinformasi yang memang mempunyai manfaat nilai tambah bagi pembaca atau pemustaka. Saat ini dengan diseminasi informasi yang dapat diakses di manapun akan memudahkan pemustaka untuk memperoleh informasi. Dalam perkembangan selanjutnya dalam teknologi digital ini akan berkembang menjadi institusi repository 
di mana kekayaan koleksi yang ada diperguruan tinggi dapat dinikmati oleh pengguna atau pemustaka secara digital . Koleksi - koleksi yang disediakan adalah koleksi yang berkaitan dengan aktivitas kelembagaan ataupun karya-karya tentang institusi tertentu sehingga institutional repository ini menjadi portal utama dalam memperkenalkan lembaga sebagai promosi eksistensinya. Karya-karya yang didiseminasikan biasanya adalah skripsi, tesis, hasil penelitian ataupun karya karya penulisan yang ditulis oleh sivitas akademika perguruan tinggi. Konten-konten lokal ini akan menjadi salah satu unggulan sebuah perguruan tinggi. Kalau saat ini kita mendengar pemeringkatan suatu perguruan tinggi melalui webometric maka repository ini menjadi salah satu tolok ukur kualitas perguruan tinggi untuk mewujudkan world class university (WCU). Bahkan dalam diseminasi informasi karya-karya penelitian tidak tertutup kemungkinan dapat dibaca oleh para industrialis yang berminat untuk mengembangkan penelitian itu untuk dapat diaplikasikan bagi pengembangan produktivitas para industrialis itu. Seperti dikatakan oleh Prof. Ir Dwikorita, banyak produk riset unggulan telah dirasakan langsung manfaatnya oleh masyarakat, misalnya saja pengembangan sistem aplikasi terintegrasi dalam pengelolaan bus rapid transit di Indonesia seperti Trans Jakarta dan Trans Jogja. Selain itu alat terapi bagi penderita hidrosifalus yang telah diaplikasikan pada banyak pasien (Dwikorita, 2016).

Maka strategi pustakawan dalam meningkatkan kompetensi dalam pengembangan penelitian adalah memaksimalkan kemampuan dirinya dalam bidang teknologi informasi khususnya dalam strategi diseminasi penelitian agar dapat semakin ditingkatkan dalam mengadakan jejaring dengan perpustakan-perpustakaan yang dimiliki oleh perusahaan-perusahaan seperti BUMN ataupun BUMD sehingga penelitian perguruan tinggi dapat diaplikasikan pada masyarakat .

\section{Strategi Dalam Peningkatan Kompetensi pada Pengabdian Masyarakat}

Penngabdian pada masyarakat yang dilakukan oleh perguruan tinggi biasanya berupa aktivitas untuk melakukan kegiatan social yang langsung dapat dinikmati oleh masyarakat misalnya penerjunan mahasiswa untuk mngikuti kuliah kerja nyata $(\mathrm{KKN})$ yang dilakukan oleh para mahasiswa selama 2 bulan sebelum mereka lulus dari perguruan tinggi. Ataupun mungkin dapat berupa pengobatan gratis ataupun pembagian sembako pada masyarakat miskin. Maka ketika mereka mengadakan pengabdian pada masyarakat, pihak perpustakaan pun dapat melakukan pengabdian 
melalui kemampuan yang dimiliki oleh pustakawan. Sebagai contoh adalah layanan sebuah perguruan tinggi swasta di Yogyakarta berupa mobile Library di Gunung Kidul. Perpustakaan ini bekerjasama dengan kelompok salah satu kelompok KKN. Mobile Library ini melayani peminjaman di sebuah Sekolah Dasar dengan 1 buah buku yang diminatinya. Layanan ini dimaksudkan untuk menjangkau layanan membaca dan peningkatan literasi di daerah pelosok di Gunung Kidul. Perpustakaan ini memilikfasilitas Mobile Library karena mendapatkan mobil hibah yang diberikan oleh bank milik Negara.

Pengabdian lain yang dapat dilakukan oleh pustakawan adalah dengan melakukan pelatihan literasi informasi bagi anak-anak SMA misalnya. Apalagi ditengah-tengah semakin gencarnya media sosial menjadi sarana penyebaran hoax, pustakawan dapat memberikan pendidikan literasi informasi pada anak-anak usia remaja. Maka tak pelak pustakawan pun seharusnya juga turut berperan dalam gerakan menolak hoax ini. Selain memilah dan memilih informasi yang menyehatkan juga lebih sering menyelenggarakan pendidikan literasi yang diharapkan mampu menjadi seruan persuasif guna menumbuhkan nalar kritis. Dalam peradaban masyarakat Indonesia yang belum mempunyai kesadaran membaca dalam arti secara sungguh sungguh membaca untuk memperoleh sesuatu yang dibutuhkan menjadi celah yang mudah untuk dimasuki oleh kabar bohong ini.

Pustakawan dalam mengedukasi agar masyarakat tidak mudah terbius hoax selayaknya dapat dilakukan menurut jalur pendidikan yang erat kaitannya dengan dunia perpustakaan. Pustakawan dapat memulai dengan menyelenggarakan pendidikan literasi kepada pemustaka dengan mengenalkan tentang hoax, bagaimana penyebarannya dan penanggulangan hoax, siapa saja yang menjadi korban. Maka ketika mereka mengetahui paham informasi secara benar, maka penyebaran hoax diharapkan akan berkurang. Pendidikan literasi ini menjadi bagian pustakawan untuk memberikan edukasi kepada pemustaka sehingga pemustaka akan memahami benar untuk saring sebelum sharing yang artinya setiap informasi yang diperoleh harus disaring dahulu sebelum diteruskan kepada orang lain. Sehingga apabila informasi itu diyakini tidak akan memberikan manfaat bagi orang lain, maka informasi itu tidak akan disharing (Hidup,2017: 11).

Maka perpustakaan dalam mendukung Tri Dharma Perguruan tinggi ini dapat bekerjasama dengan para Kepala program studi ataupun kepala lembaga pengabdian pada masyarakat agar pustakawan ini selalu dilibatkan dalam setiap aktivitas 
perguruan tinggi sehingga peran perpustakaan melalui aktivitas pustakawan aakn semakin memperbaiki citra diri pustakawan sehingga profesi pustakawan semakin menggairahkan melalui usaha-usaha peningkatan kompetensi sehingga pustakawan akan semakin lebih professional.

\section{Kesimpulan}

Perpustakaan adalah pustakawannya, sehingga dinamisator perpustakaan adalah pustakawannya. Maka peningkatan kompetensi pustakawan semakin diperlukan menghadapi kondisi teknologi informasi yang semakin membantu pustakawan dalam melaksanakan tugas-tugas kesehariannya. Maka tak ayal banjir informasi menerpa masyarakat dari berbagai lapisan strata sosial tak terkecuali masyarakat perguruan tinggi pun mengalami banjir informasi. Kondisi ini tentu tak lepas dari pihak perpustakaan sebagai pengelola informasi untuk terus memberikan layanan terbaiknya bagi pemustakanya sehingga peningkatan keahlian agar pustakawan lebih berprofesional tetap terus dilakukan sesuai tanggungjawab yang diemban pihak perpustakaan

\section{Saran}

1. Peningkatan profesionalisme melalui peningkatan kompetensi pustakawan dalam membentuk pustakawan yang berorientasi pada subjek spesialist dapat mendukung kinerja sebuah perpustakan menuju perpustakaan riset

2. Perpustakaan memperluas jaringan sehingga koleksi melalui akses online semakin memperkaya publikasi ilmiah di perpustakaan .

\section{Daftar Pustaka}

Candra Dewi.Tristiana. 2006. "Membangun Citra Exellent Service di Perpustakaan Perguruan Tinggi" Makalah Seminar "Mewujudkan Layanan Prima perpustakaan Universitas Atma Jaya Yogyakarta. 22 September 2006.

Hidup . 2017. Saring Sebelum Sharing, Tahun 7 No 7

http://www.academicindonesia.com/tri-dharma-perguruan-tinggi dikutip 2 Juni 2017)

Husna,Jazimatul .2016. Kontribusi Perpustakaan Dalam Implementasi Empat Pilar Perpustakaan Untuk Peningkatan Knowledge Management Masyarakat Kompetitif. Lokakarya Nasional Dokumentasi dan Informasi : Pengelolaan Data, Informasi dan Pengetahuan untuk Mendukung Pembangunan Repositor, Jakarta : PDII LIPI 
Karnawati, Dwikorita. 2016.”Inovasi Tingkatkan Daya Saing” Bernas 24 Septemberv2016

Keputusan Mendiknas nomor 25 tahun 2008 Tentang Standar Tenaga perpustakan Sekolah/Madrasah

Laxman, Pendit, Putu . 2011. "Melacak Jejak Langkah Penggunaan Teori dalam penelitian Ilmu Perpustakaan \& Informasi”. Librari, Jurnal Ilmu Perpustakaan dan Informasi Vol 1 No 2 .

M. Reitz, Joan. Online Dictionary of Library and Information Science, 2002 dalam Khusnul Khotimah ,Multi Dimensi Pustakawan di Perpustakaan Pada Era Teknologi Informasi.

Menpan No 132/KEP/M. PAN/12/2002

Peraturan Jabatan Fungsional Pustakawan pada Universitas Atma Jaya Yogyakarta nomor 01/perat/YSRY/2009

Permana, Aan .2010. Profesi Pustakawan. Workshop Revitalisasi Pendidikan dan Profesi Pustakawan Surakarta, 21 Desember 2010 Solo : UNS

Raharjo, Sungkowo. 2010. Standar Kompetensi dan Sertifikasi Pustakawan : Tantangan, Tuntutan dan Keharusan Pustakawan Profesional . Sidang Pengukuhan Pustakawan Utama, Jakarta : PNRI.

Rahman Saleh, Abdul. 2004. "Manfaat standar kompetensi dan etika profesi dalam peningkatan profesionalisme pustakawan". Disampaikan pada Rapat Koordinasi Tim Penilai Pustakawan di Jakarta, tanggal 5 Oktober 20042 Ketua Bidang IV Pengurus Pusat Ikatan Pustakawan Indonesia, membidangi Perpustakaan Perguruan Tinggi

Sulistyo_Basuki .1993. Pengantar Ilmu Perpustakaan,Jakarta : Gramedia Pustaka Utama.

Suwarno, Wiji 2011. Perpustakaan \& Buku Wacana Penulisan \& Penerbitan. Yogyakarta :Ar-Ruzz Media.

Undang-undang No 43 tahun 2007 Tentang Perpustakaan

Yulianto, Eko. 2017. Jurnal Ilmiah Mulai Tumbuh, Publikasi Ilmiah Bermutu Lahir dari Riset yang Bermutu Pula, Kompas 8 Maret 2017 